Jurnal Keperawatan Hang Tuah (Hang Tuah Nursing
Journal)
e-ISSN 0000-0000

\title{
HUBUNGAN DUKUNGAN SUAMI TERHADAP MOTIVASI IBU DALAM MERAWAT ANAK DENGAN AUTIS
}

\author{
Joshy Herliani ${ }^{1}$, Jumaini ${ }^{2}$, Erna Marni ${ }^{3}$
}

Program Studi IImu Keperawatan STIKes Hang Tuah Pekanbaru

Korespondensi email:1 joshyherliani28@gmail.com

\begin{tabular}{|c|c|}
\hline Histori artikel & Abstrak \\
\hline $\begin{array}{l}\text { Received: } \\
11 \text { Desember } 2020 \\
\\
\text { Accepted: } \\
15 \text { Februari } 2021 \\
\\
\text { Published: } \\
16 \text { Februari } 2021\end{array}$ & $\begin{array}{l}\text { Autis adalah suatu gangguan perkembangan yang terjadi pada } \\
\text { anak-anak yang tidak mampu berinteraksi sosial dan hanya } \\
\text { terfokus pada dunianya sendiri. Ibu dengan anak autis } \\
\text { membutuhkan dukungan dan berbagi peran dengan suami agar } \\
\text { dapat memberikan perawatan yang baik kepada anak autis. } \\
\text { Penelitian ini bertujuan untuk mengetahui hubungan dukungan } \\
\text { suami terhadap motivasi ibu dalam merawat anak dengan autis. } \\
\text { Jenis penelitian adalah penelitian kuantitatif dengan metode } \\
\text { korelasi menggunakan pendekatan cross sectional. Jumlah sampel } \\
\text { pada penelitian ini sebanyak } 33 \text { orang responden yang diambil } \\
\text { menggunakan teknik accidental sampling. Alat ukur yang } \\
\text { digunakan berupa kuesioner. Analisa yang digunakan adalah } \\
\text { analisa bivariat dengan uji statistik chi-square. Hasil penelitian yang } \\
\text { diperoleh adalah tidak terdapat hubungan yang signifikan antara } \\
\text { dukungan suami terhadap motivasi ibu dalam merawat anak } \\
\text { dengan autis dengan p-value }=0,611>\text { ( } \alpha 0,05) \text {. Kepada orang tua } \\
\text { disarankan untuk saling mendukung dan bekerja sama dalam } \\
\text { memberikan perawatan kepada anak autis agar perawatan yang } \\
\text { diberikan dapat lebih optimal }\end{array}$ \\
\hline
\end{tabular}

Kata kunci : Autis, Dukungan suami, Merawat anak autis, dan Motivasi ibu.

\begin{tabular}{l}
\hline Abstract \\
\hline Autism is a developmental disorder that occurs in children who \\
unable to interact with social and only focus on their world. Mothers
\end{tabular}


need supporting and role sharing with their husband to provide good caring to children. The purpose of this study is to determine the relationship between husband support with mother motivation in caring for children with autism. This is a quantitative study with correlation design and cross sectional approach. The samples were 33 respondents taken by accidental sampling technique. The instrument is questionnaire. The analyze used bivariate with chisquare test. The result showed is there no relationship between husband support with mother motivation in caring for children with autism with $p$ value $=0,611>(\alpha 0,05)$. It is recommended to parents in order to supporting and coordinate each other and to giving the good caring to their children to obtain optimal caring.

Keywords: Autism, Husband Support, Caring for a Child with Autism, and Mother Motivation

\section{PENDAHULUAN}

Angka kejadian autis mengalami peningkatan setiap tahunnya. Data dari Centers for Disease Control and Prevention (CDC) (2016) menyatakan di seluruh dunia terdapat 1 dari 68 anak teridentifikasi autis. Angka kejadian autis terus mengalami peningkatan sejak tahun 2000 dengan prevalensi 6,7 per 1000 anak hingga 14,6 per 1000 anak pada tahun 2012. Di Amerika Serikat jumlah anak autis pada tahun 2016 tercatat 346,978 pada anak usia 8 tahun dengan IQ 32\%. Sedangkan di Indonesia menurut Direktur Bina Kesehatan Jiwa Kementrian Kesehatan terdapat lebih dari 112.000 anak yang menyandang autis (Hazliansyah, 2013). Data yang diperoleh dari Dinas Pendidikan dan Kebudayaan Provinsi Riau (2015) terdapat 335 anak penderita autis di Provinsi Riau dan 145 anak diantaranya berada di 12 Sekolah Luar Biasa (SLB) yang berada di Kota Pekanbaru. Survei yang dilakukan oleh peneliti pada bulan November-Desember 2016 dari 5 SLB, 1 tempat terapi dan 1 Pusat Layanan Autis (PLA) di Pekanbaru terdapat 127 anak penyandang autis.

Autis adalah suatu gangguan perkembangan yang terjadi pada anak-anak yang tidak mampu berinteraksi sosial dan hanya terfokus pada dunianya sendiri sehingga orang tua perlu memasuki dunia anak autis untuk membantu anak masuk ke dunia luar (Muhith, 2015). Kehadiran anak autis didalam sebuah keluarga dapat mempengaruhi kehidupan keluarga tersebut, terutama pada keadaan psikologis orang tua.

Orang tua sangat mengetahui karakteristik anaknya (Graha, 2007). Pengalaman orang tua akan mempengaruhi kesiapan orang tua menjalankan pengasuhan kepada anaknya 
(Supartini, 2004). Penelitian yang dilakukan oleh Muniroh (2010) menyatakan bahwa pengalaman orang tua yang memiliki anak dengan autis merupakan suatu ujian bagi orang tua dan dalam merawat serta mendidik anak dengan autis tidaklah mudah.

Anak autis membutuhkan perawatan yang beragam sehingga untuk memberikan perawatan yang baik dan sesuai dengan kondisi individual anak, orang tua perlu mempersiapkan tenaga, pikiran, dan biaya yang tidak sedikit (Ginanjar, 2008). Orang tua yaitu ayah dan ibu merupakan seseorang yang berperan penting dalam perawatan anak. Selain sebagai kepala keluarga, ayah merupakan seseorang yang sangat berperan bagi anak terutama dalam membangun kecerdasan emosional anak (Rezky, 2010). Selain ayah, ibu merupakan seseorang yang paling dekat dengan anak (Surbakti, 2009). Seorang ibu harus memiliki kesiapan untuk membantu anak menemukan jalan potensinya masing-masing dikarenakan setiap anak dilahirkan dengan potensi yang berbeda dan seberapa besar potensi itu bisa menjadi berkembang bergantung pada kesungguhan ibu dalam mengembangkan dan merawatnya (Malahayati \& Hairunnisa, 2009).

Penelitian yang dilakukan oleh Aziz dan Fatma (2013) menyatakan perawatan khusus pada anak autis memberikan efek stres bagi ibu karena perilaku agresif anak dan hilangnya respon interpersonal pada anak sehingga ibu membutuhkan dukungan sosial dalam menghadapi masalah yang ibu alami. Menurut Harnilawati (2013) dukungan sosial merupakan suatu keadaan yang bermanfaat bagi seseorang yang diperoleh dari orang lain seperti keluarga, suami, teman dan lingkungan sekitar.

Penelitian yang dilakukan oleh Noor, Indriati dan Elita (2014) menyatakan ibu membutuhkan dukungan fisik, informal, waktu, tanggung jawab, dan berbagi peran dengan suami sehingga dapat menurunkan tingkat depresi ibu dalam merawat anak dengan autis. Kurangnya dukungan sosial sangat berpengaruh dalam menumbuhkan motivasi pada seseorang.

Motivasi adalah sesuatu yang mendorong atau pendorong seseorang bertingkah laku untuk mencapai suatu tujuan tertentu yang berasal dari dalam diri seseorang atau rangsangan dari pihak luar (Saam \& Wahyuni, 2013). Motivasi dan perilaku merupakan suatu hal yang berkaitan. Menurut konsep Woodhworth dalam Khairani (2016), perilaku terjadi karena adanya motivasi atau dorongan yang mengarahkan individu untuk bertindak, dimana apabila lemahnya motivasi yang didapat oleh individu dapat berpengaruh kepada perilaku individu. Menurut Wuryanano (2007), perilaku positif maupun negatif dipengaruhi oleh sikap seseorang. Penelitian yang dilakukan oleh Kurnia, Supiyati dan Khairunnisa (2014) menyatakan terdapat hubungan antara sikap ibu dengan motivasi ibu dalam merawat anak dengan autis, sikap positif atau negatif ibu dapat dipengaruhi salah satunya dari pengaruh orang lain yang 
dianggap penting. Motivasi dapat terpelihara jika ada dukungan dari lingkungan sekitar, terutama dari orang-orang terdekat (Sarosa, 2005).

Hasil survei pendahuluan yang dilakukan oleh peneliti pada tanggal 10-13 Desember 2017 di Terapi Special Kids di Pekanbaru kepada 5 ibu yang memiliki anak autis, dua ibu mengatakan mendapatkan dukungan sosial secara penuh dari suami dalam merawat anak, dua ibu yang lain mengatakan suami ikut berperan dalam merawat anak namun tidak sepenuhnya sedangkan satu ibu mengatakan suami tidak berperan dalam perawatan anak, suami hanya memberikan dukungan secara finansial. Seluruh ibu mengatakan bahwa dukungan suami sangat berpengaruh dalam merawat anak dengan autis karena merawat anak autis perlu kerja sama suami dan istri, kesabaran yang besar, tenaga, pikiran, dan biaya yang tidak sedikit.

Berdasarkan uraian di atas terlihat fenomena bahwa perilaku seseorang dapat dipengaruhi oleh tinggi atau lemahnya motivasi. Kurangnya motivasi dapat berpengaruh pada perilaku atau sikap ibu dalam memberikan perawatan. Sedangkan kurangnya dukungan dari orang terdekat dapat mempengaruhi sikap ibu dalam memberikan perawatan kepada anak autis, sehingga peneliti tertarik untuk melakukan penelitian terkait dengan hubungan dukungan suami terhadap motivasi ibu dalam merawat anak dengan autis.

\section{METODOLOGI}

Penelitian ini merupakan jenis penelitian kuantitatif dengan metode kolerasi menggunakan pendekatan cross sectional. Lokasi penelitian dengan jumlah masing-masing populasi adalah Klinik Terapi Autis Permata Hati (15), Terapi Special Kids (20), dan Pusat Layanan Autis (PLA) (16) di Pekanbaru. Sehingga total populasi pada penelitian ini adalah 51 orang. Pada penelitian ini menggunakan sampel minimum untuk penelitian kuantitatif. Sampel pada penelitian ini adalah ibu yang memilki anak autis yang berjumlah 33 ibu dengan teknik accidental sampling. Sampel pada penelitian ini kepada 33 ibu yang memiliki anak dengan autis yang memenuhi kriteria inklusi. Kriteria inklusi pada penelitian ini adalah ibu yang memiliki suami yang masih hidup, berdomisili di Pekanbaru, sehat jasmani dan mental, dapat berkomunikasi secara verbal dan nonverbal.

HASIL

Karakteristik responden

Tabel 1

Distribusi Frekuensi Berdasarkan Karakteristik Ibu yang Memiliki Anak Autis

Karakteristik Jumlah Persentase (\%) 


\begin{tabular}{|c|c|c|}
\hline \multicolumn{3}{|l|}{ Identitas ibu } \\
\hline Usia & & \\
\hline $\begin{array}{l}\text { Dewasa Muda } \\
\text { (18-40 tahun) }\end{array}$ & 22 & 66,7 \\
\hline $\begin{array}{l}\text { Dewasa Tengah } \\
\text { (40-65 tahun) }\end{array}$ & 11 & 33,3 \\
\hline $\begin{array}{l}\text { Status } \\
\text { perkawinan }\end{array}$ & & \\
\hline Menikah & 32 & 97 \\
\hline Bercerai & 1 & 3 \\
\hline $\begin{array}{l}\text { Pendidikan } \\
\text { terakhir }\end{array}$ & & \\
\hline SD & 1 & 3 \\
\hline SMA & 13 & 39,4 \\
\hline Perguruan tinggi & 15 & 45,5 \\
\hline Pekerjaan ibu & & \\
\hline IRT & 19 & 57,6 \\
\hline Karakteristik & Jumlah & Persentase (\%) \\
\hline Wiraswasta & 5 & 15,2 \\
\hline PNS & 1 & 3 \\
\hline Dan lain-lain & 3 & 9,1 \\
\hline Identitas anak & & \\
\hline Usia anak & & \\
\hline $\begin{array}{l}\text { Pra sekolah (3-6 } \\
\text { tahun) }\end{array}$ & 14 & 42,4 \\
\hline $\begin{array}{l}\text { Anak sekolah }(7- \\
11 \text { tahun) }\end{array}$ & 15 & 45,5 \\
\hline $\begin{array}{l}\text { Remaja } \\
\text { tahun) }\end{array}$ & 2 & 6,1 \\
\hline $\begin{array}{l}\text { Dewasa muda } \\
\text { (18-40 tahun) }\end{array}$ & 2 & 6,1 \\
\hline $\begin{array}{l}\text { Jenis kelamin } \\
\text { anak }\end{array}$ & & \\
\hline Laki-laki & 27 & 81,8 \\
\hline Perempuan & 6 & 18,2 \\
\hline
\end{tabular}

Responden berusia dewasa muda yaitu 22 orang $(66,7 \%)$, berstatus menikah yaitu 32 orang $(97 \%)$, pendidikan terakhir adalah perguruan tinggi yaitu 15 orang $(45,5 \%)$, bekerja sebagai 
ibu rumah tangga (IRT) yaitu 19 orang $(57,6 \%)$. Usia anak adalah usia sekolah yaitu 15 orang $(45,5 \%)$ dan berjenis kelamin laki laki yaitu 27 orang $(81,8 \%)$.

Dukungan Suami

Tabel 2

Distribusi Frekuensi Dukungan Suami

\begin{tabular}{llll}
\hline No & Dukungan Suami & Jumlah & $(\%)$ \\
\hline 1 & Baik & 18 & 54,5 \\
2 & Buruk & 15 & 45,4 \\
\hline & Jumlah & 33 & 100
\end{tabular}

Lebih dari setengah memiliki dukungan suami baik adalah 18 orang $(54,5 \%)$ dan yang buruk sebanyak 15 orang $(45,4 \%)$.

Tabel 3

Distribusi Frekuensi Dukungan Yang didapatkan Ibu yang Memiliki Anak Autis

\begin{tabular}{lllllll}
\hline Bentuk & \multicolumn{3}{c}{ Kategori } & \multicolumn{3}{c}{ Total } \\
\cline { 2 - 7 } dukungan & $\begin{array}{l}\text { Bai } \\
\mathrm{k}\end{array}$ & $\begin{array}{c}\text { Bur } \\
\text { uk }\end{array}$ & $\begin{array}{l}\text { Ju } \\
\text { mla }\end{array}$ & $\%$ \\
& & & & & $\mathrm{~h}$ & \\
\hline Emosiona & 22 & 66, & 11 & 33, & 33 & 100 \\
I & & 7 & & 3 & & \\
\hline Instrumen & 17 & 51, & 16 & 48, & 33 & 100 \\
tal & & 5 & & 5 & & \\
\hline Informasi/ & 18 & 54, & 15 & 45, & 33 & 100 \\
Pengetah & & 5 & & 5 & & \\
uan & & & & & & \\
\hline Penilaian & 19 & 57, & 14 & 42, & 33 & 100 \\
& & 6 & & 4 & & \\
\hline
\end{tabular}

Pada pembagian bentuk dukungan yang baik masing-masing didapatkan yaitu dukungan emosional sebanyak 22 orang (66,7\%), dukungan instrumental sebanyak 17 orang $(51,5 \%)$, dukungan informasi/pengetahuan sebanyak 18 orang $(54,5 \%)$, dan dukungan penilaian sebanyak19 orang $(57,6 \%)$.

Motivasi lbu

Tabel 4

Distribusi Frekuensi Motivasi lbu

\begin{tabular}{cccc}
\hline No & $\begin{array}{c}\text { Motivasi lbu } \\
\text { dalam Merawat }\end{array}$ & Jumlah & $(\%)$ \\
\hline 1 & Tinggi & 17 & 51,5
\end{tabular}




\begin{tabular}{cccc}
2 & Rendah & 16 & 48,5 \\
\hline Jumlah & 33 & 100
\end{tabular}

Lebih dari setengah responden memiliki motivasi tinggi dalam merawat anak adalah 17 orang $(51,5 \%)$ dan yang memiliki motivasi rendah dalam merawat anak hanya 16 orang $(48,5 \%)$.

Tabel 5

Hubungan Dukungan Suami Terhadap Motivasi Ibu dalam Merawat Anak dengan Autis

\begin{tabular}{|c|c|c|c|c|c|c|c|}
\hline \multirow{5}{*}{$\begin{array}{l}\text { Dukun } \\
\text { gan } \\
\text { Suami }\end{array}$} & \multicolumn{4}{|c|}{ Motivasi Ibu dalam } & \multirow{3}{*}{\multicolumn{2}{|c|}{ Total }} & $P$ \\
\hline & \multirow{2}{*}{\multicolumn{3}{|c|}{$\begin{array}{l}\text { Merawat } \\
\text { dengan Autis }\end{array}$}} & Anak & & & Val \\
\hline & & & & & & & ue \\
\hline & \multicolumn{2}{|c|}{ Tinggi } & \multicolumn{2}{|c|}{ Rendah } & & & \\
\hline & $\mathrm{N}$ & $\%$ & $\mathrm{~N}$ & $\%$ & $\mathrm{~N}$ & $\%$ & \\
\hline \multirow[t]{2}{*}{ Baik } & 10 & 55 & 8 & 44 & 18 & 10 & 0,8 \\
\hline & & ,6 & & 4 & & 0 & 74 \\
\hline Buru & 7 & 46 & 8 & 53 & 15 & 10 & \\
\hline k & & ,7 & & 3 & & 0 & \\
\hline Juml & 17 & 51 & 16 & 48 & 33 & 10 & \\
\hline ah & &, 5 & & 5 & & 0 & \\
\hline
\end{tabular}

Hasil uji statistik diperoleh $p$ value 0,874 yaitu $p$ value $>\alpha 0,05$ artinya tidak ada hubungan antara dukungan suami dengan motivasi ibu.

Tabel 6

Hubungan Dukungan Emosional Suami Terhadap Motivasi Ibu dalam Merawat Anak dengan Autis

\begin{tabular}{|c|c|c|c|c|c|c|c|}
\hline \multirow{4}{*}{$\begin{array}{l}\text { Dukung } \\
\text { an } \\
\text { Emosio } \\
\text { nal } \\
\text { Suami }\end{array}$} & \multicolumn{4}{|c|}{ Motivasi Ibu dalam } & \multirow{2}{*}{\multicolumn{2}{|c|}{ Total }} & $P$ \\
\hline & \multicolumn{4}{|c|}{$\begin{array}{l}\text { Merawat } \\
\text { dengan Autis }\end{array}$} & & & $\begin{array}{l}\text { Va } \\
\text { lu }\end{array}$ \\
\hline & \multicolumn{2}{|c|}{ Tinggi } & \multicolumn{2}{|c|}{ Rendah } & & & \\
\hline & $\mathrm{N}$ & $\%$ & $\mathrm{~N}$ & $\%$ & $\mathrm{~N}$ & $\%$ & \\
\hline \multirow[t]{2}{*}{ Baik } & \multirow[t]{2}{*}{11} & 50 & 11 & 50,0 & 22 & 10 & 1 \\
\hline & & ,0 & & & & 0 & 00 \\
\hline \multirow[t]{2}{*}{ Buruk } & \multirow[t]{2}{*}{6} & 54 & 5 & 45,5 & 11 & 10 & \\
\hline & &, 5 & & & & 0 & \\
\hline \multirow[t]{2}{*}{ Jumlah } & \multirow[t]{2}{*}{17} & 51 & 16 & 48,5 & 33 & 10 & \\
\hline & &, 5 & & & & 0 & \\
\hline
\end{tabular}


Hasil uji statistik diperoleh $p$ value 1,000 yaitu $p$ value $>\alpha 0,05$ artinya tidak ada hubungan antara dukungan emosional suami dengan motivasi ibu.

Pada dukungan instrumental hasil uji statistik diperoleh $p$ value 1,000 yaitu $p$ value $>\alpha 0,05$ artinya tidak ada hubungan antara dukungan instrumental suami dengan motivasi ibu.

Tabel 7

Hubungan Dukungan Instrumental Suami Terhadap Motivasi Ibu dalam Merawat Anak dengan Autis

\begin{tabular}{|c|c|c|c|c|c|c|c|}
\hline \multirow{5}{*}{$\begin{array}{l}\text { Dukung } \\
\text { an } \\
\text { Instrum } \\
\text { ental } \\
\text { Suami }\end{array}$} & \multicolumn{4}{|c|}{ Motivasi Ibu dalam } & \multirow{2}{*}{\multicolumn{2}{|c|}{ Total }} & $P$ \\
\hline & \multicolumn{4}{|c|}{$\begin{array}{l}\text { Merawat Anak } \\
\text { dengan Autis }\end{array}$} & & & $\begin{array}{l}\text { Val } \\
\text { ue }\end{array}$ \\
\hline & & & & & & & \\
\hline & \multicolumn{2}{|c|}{ Tinggi } & \multicolumn{2}{|c|}{ Rendah } & & & \\
\hline & $\mathrm{N}$ & $\%$ & $\mathrm{~N}$ & $\%$ & $\mathrm{~N}$ & $\%$ & \\
\hline \multirow[t]{2}{*}{ Baik } & 9 & 52 & 8 & 47,1 & 17 & 10 & 1,0 \\
\hline & & ,9 & & & & 0 & 00 \\
\hline \multirow[t]{2}{*}{ Buruk } & 8 & 50 & 8 & 50,0 & 16 & 10 & \\
\hline & &, 0 & & & & 0 & \\
\hline \multirow[t]{2}{*}{ Jumlah } & 17 & 51 & 16 & 48,5 & 33 & 10 & \\
\hline & &, 5 & & & & 0 & \\
\hline
\end{tabular}

Tabel 8

Hubungan Dukungan Informasi/ Pengetahuan Suami Terhadap Motivasi Ibu dalam Merawat Anak dengan Autis

\begin{tabular}{|c|c|c|c|c|c|c|c|}
\hline \multirow{3}{*}{$\begin{array}{l}\text { Dukung } \\
\text { an } \\
\text { Informa } \\
\text { si }\end{array}$} & \multicolumn{4}{|c|}{$\begin{array}{l}\text { Merawat Anak } \\
\text { dengan Autis }\end{array}$} & \multicolumn{2}{|c|}{ Total } & \multirow[t]{3}{*}{$\begin{array}{l}\mathrm{P} \\
\text { Valu } \\
e\end{array}$} \\
\hline & \multicolumn{2}{|c|}{ Tinggi } & \multicolumn{2}{|c|}{ Rendah } & & & \\
\hline & $\mathrm{N}$ & $\%$ & $\mathrm{~N}$ & $\%$ & $\mathrm{~N}$ & $\%$ & \\
\hline \multirow[t]{3}{*}{ Baik } & 1 & 5 & 8 & 4 & 1 & 10 & 0,87 \\
\hline & 0 & 5 , & & 4, & 8 & 0 & 4 \\
\hline & & 6 & & 4 & & & \\
\hline \multirow[t]{3}{*}{ Buruk } & 7 & 4 & 8 & 5 & 1 & 10 & \\
\hline & & 6 , & & 3 , & 5 & 0 & \\
\hline & & 7 & & 5 & & & \\
\hline
\end{tabular}




\begin{tabular}{lllllll}
\hline Jumla & 1 & 5 & 1 & 4 & 3 & 10 \\
$\mathrm{~h}$ & 7 & 1, & 6 & 8, & 3 & 0 \\
& & 5 & & 5 & &
\end{tabular}

Hasil uji statistik diperoleh $p$ value 0,874 yaitu $p$ value $>\alpha 0,05$ artinya tidak ada hubungan antara dukungan informasi/ pengetahuan suami dengan motivasi ibu.

Tabel 9

Hubungan Dukungan Penilaian Suami Terhadap Motivasi Ibu dalam Merawat Anak dengan Autis

\begin{tabular}{|c|c|c|c|c|c|c|c|}
\hline \multirow{5}{*}{$\begin{array}{l}\text { Dukun } \\
\text { gan } \\
\text { Penilai } \\
\text { an } \\
\text { Suami }\end{array}$} & \multicolumn{4}{|c|}{ Motivasi Ibu dalam } & \multicolumn{2}{|c|}{ Total } & \multirow{3}{*}{$\begin{array}{l}\mathrm{P} \\
\mathrm{Va} \\
\mathrm{ue}\end{array}$} \\
\hline & \multicolumn{3}{|c|}{$\begin{array}{l}\text { Merawat } \\
\text { dengan Autis }\end{array}$} & \multirow[t]{2}{*}{ Anak } & & & \\
\hline & & & & & \\
\hline & \multicolumn{2}{|c|}{ Tinggi } & \multicolumn{2}{|c|}{ Rendah } & & & \\
\hline & $\mathrm{N}$ & $\%$ & $\mathrm{~N}$ & $\%$ & $\mathrm{~N}$ & $\%$ & \\
\hline \multirow[t]{2}{*}{ Baik } & 1 & 63 & 7 & 36,8 & 1 & 100 & 0,2 \\
\hline & 2 & 2 & & & 9 & & 28 \\
\hline \multirow[t]{2}{*}{ Buruk } & 5 & 35 & 9 & 64,3 & 1 & 100 & \\
\hline & & 7 & & & 4 & & \\
\hline Jumla & 1 & 51 & 1 & 48,5 & 3 & 100 & \\
\hline $\mathrm{h}$ & 7 & 5 & 6 & & 3 & & \\
\hline
\end{tabular}

Hasil uji statistik diperoleh $p$ value 0,228 yaitu $p$ value $>\alpha 0,05$ artinya tidak ada hubungan antara dukungan informasi/ pengetahuan suami dengan motivasi ibu.

\section{PEMBAHASAN}

Karakteristik responden

Hasil analisis menunjukkan bahwa sebagian besar responden berusia dewasa muda (18-40 tahun) yaitu 22 orang (66,7\%). Usia dewasa muda merupakan masa peralihan dari usia remaja, dimana pernikahan dan pembentukan keluarga umumnya mulai terjadi. Pada masa ini seseorang biasanya mulai membangun apa yang ada pada dirinya dan mencapai kemandiriannya. Hasil penelitian yang dilakukan oleh Muliana, Putri \& Panjaitan (2014), responden yang paling banyak berusia $36-60$ tahun yaitu 44 orang $(89,8 \%)$. Wirakusuma (2010), mengatakan bahwa usia 20 sampai 60 tahun merupakan usia produktif. Menurut Dewi (2014), usia produktif berada pada rentang usia 15-59 tahun.

Menurut Harjowinoto dan Susanto (2008), usia produktif adalah usia dimana seseorang berada kondisi prima dan badan dalam kondisi prima, sehingga seseorang tersebut memiliki semangat serta motivasi dalam hidupnya. Berdasarkan uraian tersebut dapat disimpulkan 
bahwa usia orang tua dengan anak autis berada pada tahap usia produktif, dimana pada masa usia ini orang tua diharapkan dapat memberikan perawatan terbaik kepada keluarganya.

Pada karakteristik status perkawinan, hasil analisis menunjukkan sebagian besar responden berstatus menikah yaitu 32 orang (97\%), sedangkan yang bercerai hanya 1 orang (3\%). Orang tua yang tidak saling mendukung dan bekerja sama dalam memberikan perawatan kepada anak dapat mengakibatkan pertengkaran dan berakhir pada perceraian. Penelitian yang dilakukan oleh Kusumastuti (2014), subjek menyatakan setelah anaknya didiagnosa terkena autis oleh dokter subjek sering bertengkar dengan suami. Suami tidak ikut andil dan mendukung subjek dalam merawat anak autis sehingga menyebabkan perceraian.

Pada karakteristik pendidikan terakhir, hasil analisis menunjukkan bahwa sebagian besar pendidikan terakhir responden adalah perguruan tinggi yaitu berjumlah 15 orang (45,5\%). Hasil penelitian yang dilakukan oleh Mashabi dan Tajudin (2009), persentase terbanyak pendidikan terakhir responden adalah sarjana yaitu 17 orang (56,7\%). Hasil penelitian dari Pratiwi (2013), menyatakan pendidikan terakhir ibu yang memiliki anak autis umumnya lulusan sarjana. Orang tua yang memiliki pendidikan tinggi akan lebih memahami tumbuh kembang anaknya. Menurut Saputra (2007), semakin berpendidikan seseorang, maka semakin berprestasi seseorang tersebut.

Hal ini juga didukung oleh teori motivasi menurut David Mc Clelland dalam Hidayat (2009), dimana kebutuhan berprestasi dapat ditunjukkan dengan keinginan seseorang untuk melakukan sesuatu dengan lebih baik. Sehingga dapat disimpulkan bahwa kebanyakan ibu yang memiliki anak autis memiliki pendidikan yang baik, sehingga diharapkan dapat memberikan perawatan yang baik kepada anaknya.

Pada karakteristik pekerjaan, hasil analisis menunjukkan bahwa sebagian besar responden tidak memiliki pekerjaan (IRT) yaitu berjumlah 19 orang $(57,6 \%)$. Penelitian ini sejalan dengan penelitian yang dilakukan oleh Pratiwi (2013), dimana persentase terbesar pekerjaan ibu adalah IRT dengan persentase $70 \%$. Penelitian yang dilakukan oleh Effendi (2014), sebagian besar ibu yang memiliki anak autis merupakan ibu rumah tangga (IRT) dengan persentase $86,6 \%$.

Menurut Kartajaya (2005), ibu rumah tangga adalah ibu yang menghabiskan waktunya dirumah untuk mengatur segala keperluan rumah mulai dari mengatur keperluan keluarga sampai mengurus suami dan anak. Ibu berbagi peran dengan suami yang mencari nafkah dan ibu yang bertanggung jawab atas urusan rumah tangga. Tim Pengembangan Ilmu Pendidikan (2007), menyatakan bahwa wanita yang menjadi ibu rumah tangga dapat meningkatkan keluarga yang sejahtera. Berdasarkan uraian tersebut menunjukkan bahwa kebanyakan ibu 
yang memiliki anak autis merupakan ibu yang tidak memiliki pekerjaan (IRT) sehingga diharapkan dapat memberikan perawatan yang optimal kepada anak.

Pada identitas anak, hasil analisis menunjukkan bahwa jumlah anak autis berusia yang paling banyak adalah usia anak sekolah (7-11 tahun) yaitu 15 orang (45,5\%). Hal ini dikarenakan penelitian dilakukan di tempat terapi dimana pada masa ini orang tua mulai mengajarkan anaknya untuk bersosialisasi dengan lingkungannya, sehingga orang tua lebih giat untuk memberikan terapi kepada anaknya. Hasil penelitian yang dilakukan oleh Effendi (2014), menyatakan dimana usia anak paling banyak yaitu berusia 8-9 tahun dengan persentase $23,3 \%$.

Sedangkan untuk jenis kelamin anak, hasil analisis menunjukkan bahwa sebagian besar anak autis berjenis kelamin laki-laki yang berjumlah 27 orang $(81,8 \%)$. Hasil penelitian yang dilakukan oleh Mashabi dan Tajudin (2009) dimana jenis kelamin anak penyandang autis persentase terbesar adalah anak laki-laki yaitu berjumlah 24 orang (80\%). Hasil penelitian yang dilakukan oleh Apriani (2016) menyatakan bahwa penyandang autis terbanyak adalah anak laki-laki yaitu 20 orang (74,1\%). Anak laki-laki lebih rentan menyandang sindroma autis dibanding anak perempuan. Hal ini dikarenakan otak janin anak perempuan mendapat banyak perlindungan hormon estrogen dari tubuhnya sendiri dan ibunya dibandingan janin anak lakilaki. Akibatnya, jika terjadi gangguan baik trauma ataupun infeksi, otak janin anak perempuan lebih banyak terlindungi hormon estrogen sehingga tidak berat efek gangguannya seperti pada anak laki-laki (Siregar, 2016). Dari data diatas dapat disimpulkan bahwa penderita autis lebih banyak terkena pada anak laki-laki dibandingkan anak perempuan yang dipengaruhi oleh hormon estrogen.

Dukungan suami

Berdasarkan hasil analisis univariat dari 33 responden diketahui bahwa lebih dari setengah responden memiliki dukungan suami baik yaitu 18 orang (54,5\%). Menurut Effendi dan Makhfudli (2009), dukungan sosial sangat diperlukan seseorang didalam setiap siklus kehidupannya dan pada saat seseorang dalam menghadapi masalahnya. Peran keluarga sangat diperlukan untuk menjalani masa-masa sulit tersebut. Dukungan sosial bisa didapatkan dari keluarga terdekat salah satunya adalah suami. Penelitian ini sejalan dengan penelitian yang dilakukan oleh Rahmawati, Machmuroch, dan Nugroho (2013), menunjukkan terdapat hubungan antara penerimaan diri dan dukungan sosial dengan ibu yang memiliki anak autis. Tingkat dukungan sosial berada pada kategori tinggi yang disebabkan karena ibu yang memiliki anak autis merasakan dukungan yang terbesar berasal dari suami. Pada penelitian yang dilakukan oleh Ria (2011), menunjukkan bahwa peran serta suami sangat kecil dalam 
merawat anak dengan autis, suami cenderung tidak peduli terhadap ibu dengan anak autis, sehingga membuat kejenuhan dan kelelahan pada ibu.

Menurut Harnilawati (2013), terdapat empat jenis dukungan sosial yaitu dukungan instrumental, dukungan informasi, dukungan penilaian dan dukungan emosional. Berdasarkan hasil penelitian yang telah dilakukan oleh peneliti diketahui bahwa dari 33 orang responden, bentuk dukungan yang paling banyak pengkategorian baik adalah dukungan emosional yaitu 22 orang $(66,7 \%)$, sedangkan bentuk dukungan pengkategorian baik yang paling sedikit didapatkan oleh ibu yaitu dukungan instrumental yaitu 17 orang $(51,5 \%)$. Menurut Smet dalam Harnilawati (2013), menyatakan dukungan emosional adalah dukungan simpatik dan empati, cinta, kepercayaan serta penghargaan, sedangkan dukungan instrumental adalah bantuan yang bertujuan untuk mempermudah seseorang dalam melakukan aktivitas yang berhubungan dengan persoalan yang dihadapinya. Hasil penelitian yang dilakukan oleh Maizan, Karmiyati dan Anwar (2014), diperoleh hasil aspek dukungan sosial yang paling memberikan kontribusi dalam mengurangi stres ibu yang memiliki anak berkebutuhan khusus yaitu aspek dukungan emosional sebesar $27 \%$ sedangkan yang tidak berkontribusi yaitu dukungan instrumental sebesar 23\%. Hasil penelitian yang dilakukan oleh Milyawati (2008), diperoleh hasil sebanyak $77,4 \%$ keluarga responden memberikan dukungan dan membantu dalam merawat dan mencari informasi mengenai Autism Spectrum Disorder (ASD) tetapi tidak dalam memberikan bantuan materi untuk biaya penyembuhan anak.

Hasil penelitian dari Wijaksono (2016), menyatakan dukungan emosional yang diterima orang tua terhadap anak autis seperti orang-orang sekitar mampu memahami keadaan orang tua, peduli serta memberikan perhatian sehingga orang tua merasa dirinya dihargai oleh orang-orang sekitarnya, sedangkan dukungan instrumental yang diterima orang tua terhadap anak autis seperti orang-orang sekitar memberikan bantuan secara langsung berupa pekerjaan dalam mengasuh dan menjaga anaknya yang autis sehingga orang tua merasa lebih siap dalam menghadapi masalah yang ada, kuat dalam menjalani dan bisa menerima anaknya yang autis.

Berdasarkan uraian diatas dapat disimpulkan bahwa suami memberikan dukungan yang baik kepada istrinya. Bentuk dukungan yang diberikan salah satunya adalah dukungan emosional dimana dukungan tersebut dapat disampaikan ke istri yang sedang menghadapi dan mengurangi masalah yang dihadapinya.

Motivasi ibu

Berdasarkan hasil analisis univariat dari 33 responden diketahui bahwa lebih dari setengah responden memiliki motivasi tinggi dalam merawat anak adalah 17 orang (51,5\%). Penelitian ini sejalan dengan penelitian yang dilakukan oleh Sari, Jumaini, dan Hasanah (n.d), 
menunjukkan sebagian besar responden berada pada skor 44 dengan nilai maksimal skor motivasi tinggi yaitu 56 sebanyak 50 responden (80,6\%). Penelitian yang dilakukan oleh Kurnia, Supiyati dan Khairunnisa (2014), menunjukkan bahwa sebagian besar (44\%) ibu memiliki motivasi cukup dalam merawat anak autisme sebanyak (34\%) ibu memiliki motivasi baik dan (22\%) sisanya memiliki motivasi yang buruk dan berdasarkan hasil uji statistik terdapat hubungan motivasi ibu dalam merawat anak autisme.

Menurut Khairani (2016), motivasi dimulai dari suatu kebutuhan pada diri individu yang menyebabkan timbulnya dorongan dengan intensitas tertentu yang berfungsi mengaktifkan suatu perilaku untuk memenuhi kebutuhan yang menjadi penyebab timbulnya dorongan itu sendiri. Menurut Saam dan Wahyuni (2013), motivasi digolongkan menjadi motivasi intrinstik yaitu motivasi yang berasal dari diri seseorang tanpa adanya dorongan dari luar dan motivasi ekstrinsik yaitu motivasi yang berasal dari dorongan pihak luar.

Menurut konsep Woodhworth dalam Khairani (2016), menyatakan motivasi sebagai penyebab dari timbulnya perilaku mempunyai tiga karakteristik antara lain intensitas yaitu menyangkut lemah dan kuatnya dorongan sehingga menyebabkan individu berperilaku tertentu, pemberi arah yaitu mengarahkan individu dalam menghindari atau melakukan suatu perilaku tersebut, dan persistensi atau kecenderungan untuk mengulang perilaku secara terus menerus. Apabila ketiga hal tersebut lemah, maka motivasi tidak akan menimbulkan perilaku. Perilaku seseorang dapat dipengaruhi oleh lemahnya motivasi dari seseorang tersebut. Berdasarkan uraian diatas dapat disimpulkan bahwa tinggi atau rendahnya motivasi ibu berpengaruh terhadap perilaku ibu dalam memberikan perawatan kepada anak autis.

Hubungan dukungan suami terhadap motivasi ibu dalam merawat anak dengan autis

Berdasarkan hasil uji statistik Chi Square yang dilakukan, diperoleh nilai $p$ value $=0,874$ dengan demikian $p$ value $>\alpha 0,05$ berarti menunjukkan bahwa tidak terdapat hubungan yang bermakna antara dukungan suami dengan motivasi ibu dalam merawat anak dengan autis. Pada hasil uji statistik hubungan antara bentuk-bentuk dukungan suami dengan motivasi ibu dalam merawat anak dengan autis masing-masing didapatkan dukungan emosional suami diperoleh nilai $p$ value $=1,000$, dukungan instrumental diperoleh nilai $p$ value $=1,000$, dukungan informasi/pengetahuan suami diperoleh nilai $p$ value $=0,874$, sedangkan dukungan penilaian suami diperoleh nilai $p$ value $=0,288$ dengan demikian $p$ value $>\alpha 0,05$ berarti menunjukkan bahwa tidak terdapat hubungan yang bermakna antara bentuk-bentuk dukungan suami dengan motivasi ibu dalam merawat anak dengan autis.

Hal ini dapat dipahami bahwa dukungan suami memang bukan satu-satunya media untuk mendukung motivasi ibu dalam memberikan perawatan kepada anak autis. Hal ini mungkin dipengaruhi oleh motivasi intrinsik atau motivasi yang berasal dari dalam diri ibu yang memiliki 
anak dengan autis. Menurut Khairani (2016), salah satu faktor yang mempengaruhi motivasi adalah faktor internal seperti seseorang yang dapat mendorong atau mengarahkan untuk berusaha agar menjadi pribadi yang mandiri dan kuat serta kebutuhan untuk menjadikan dirinya sendiri yang berfungsi secara penuh sehingga mampu meraih potensinya secara total.

Hasil penelitian yang dilakukan oleh Pujiastuti (2014), 38,0\% faktor-faktor yang mempengaruhi penerimaan ibu terhadap anak autis yaitu dukungan ayah, pengetahuan tentang autis serta religius dan terdapat 62,0\% faktor-faktor lain yang mempengaruhi penerimaan ibu diluar variabel dukungan ayah, pengetahuan tentang autis dan religius. Hasil penelitian ini juga didukung oleh penelitian yang dilakukan oleh Supatri (2014), dimana faktor pendukung dalam memotivasi ibu dalam memberikan perawatan kepada anak autis yaitu salah satunya adalah nasihat dari teman, mempunyai keyakinan, tekad serta iman yang kuat.

Dukungan suami tidak hanya satu-satunya faktor yang mempengaruhi motivasi ibu dalam memberikan perawatan kepada anak autis, beberapa faktor lain lain yang mempengaruhinya salah satunya adalah pengetahuan orang tua, persepsi masyarakat sekitar serta strategi koping orang tua tersebut. Hal ini juga didukung oleh penelitian yang dilakukan oleh Kurnia, Supiyati, dan Khairunnisa (2014), menyatakan bahwa faktor-faktor yang mempengaruhi sikap ibu dalam memberikan perawatan kepada anak autis salah satunya adalah pengalaman pribadi, pengaruh kebudayaan, media massa serta faktor emosional.

Menurut Effendi dan Makhfudli (2009), dukungan sosial sangat diperlukan seseorang didalam setiap siklus kehidupannya dan sangat dibutuhkan pada saat seseorang dalam menghadapi masalah atau sakit, dan peran keluarga sangat diperlukan untuk menjalani masamasa sulit tersebut. Penelitian yang dilakukan oleh Naina (2012), diperoleh hasil bahwa semakin tinggi dukungan sosial yang didapatkan oleh ibu, maka semakin tinggi pula penerimaan mereka terhadap anak penyandang autisme. Penelitian yang dilakukan oleh Aziz dan Fatma (2013) menunjukkan adanya korelasi positif yang signifikan antara dukungan sosial dengan penyesuaian diri ibu yang memiliki anak autis, dengan demikian dapat disimpulkan bahwa variabel dukungan sosial dapat dijadikan predictor (variabel bebas) untuk memprediksi atau mengukur penyesuaian diri pada ibu yang memiliki anak autis.

Berdasarkan uraian diatas dapat disimpulkan bahwa dalam memberikan perawatan kepada anak autis ibu membutuhkan dukungan sosial salah satunya adalah suami, namun dukungan suami bukanlah satu-satunya faktor yang memotivasi ibu dalam memberikan perawatan kepada anak autis. Salah satu faktor yang memotivasi ibu dalam memberikan perawatan kepada anak autis yaitu faktor intsristik atau faktor yang berasal dari dalam diri ibu sendiri. 


\section{KESIMPULAN}

Hasil penelitian menunjukkan bahwa tidak terdapat hubungan yang signifikan antara dukungan suami terhadap motivasi ibu dalam merawat anak dengan autis dengan $p$ value $0,874>(0,05)$.

\section{SARAN}

Bagi Orang Tua yang Memiliki Anak Autis

Dapat dijadikan sebagai masukan kepada orang tua melalui tempat pendidikan dan terapi anak autis untuk saling mendukung dan bekerja sama dalam memberikan perawatan kepada anak autis agar perawatan yang diberikan kepada anak dapat lebih optimal.

Bagi Pengembangan IImu Keperawatan

Dapat dijadikan sebagai informasi bagi pengembangan ilmu keperawatan. Baiknya dukungan yang diberikan suami kepada ibu yang memiliki anak autis diharapkan dapat meningkatkan perawatan yang baik untuk diberikan kepada anak dengan autis.

Bagi Peneliti Berikutnya

Diharapkan dapat menjadi sumber informasi tambahan yang mendukung untuk penelitian selanjutanya terkait dengan hubungan dukungan suami terhadap motivasi ibu dalam merawat anak dengan autis namun dalam bentuk penelitian kualitatif agar ibu dapat mengeksplor perasaannya.

1 Joshy Herliani : Peneliti : Mahasiswa Program Studi IImu Keperawatan STIKes Hang Tuah Pekanbaru

2 Ns. Jumaini, M.Kep., Sp. Kep. J : Dosen pembimbing 1 : Dosen Program Studi Ilmu Keperawatan Universitas Riau

$3 \quad$ Ns. Erna Marni, M.Kep : Dosen pembimbing 2: Dosen Program Studi Ilmu Keperawatan STIKes Hang Tuah Pekanbaru

\section{DAFTAR PUSTAKA}

Apriani, Z. (2016). Pengaruh diet gluten free dan casein free terhadap perilaku anak autis di Makassar. Diperoleh dari http://repository.unhas.ac.id. 5 Juli 2017. Skripsi dipublikasikan

Aziz, A. \& Fatma, A. (2013). Hubungan antara dukungan sosial dengan penyesuaian diri ibu yang memiliki anak autis. Talenta Psikologi. Vol II, No. 2. 141-159. Diperoleh dari http://download.portalgaruda.org/article. 25 Oktober 2016

Centers for Disease Control and Prevention (CDC). (2016). Identified prevalence of autism spectrum disorder: ADDM Network 2000-2012

Dewi, S. R. (2014). Buku ajar keperawatan gerontik. Yogyakarta: Deepublish 
Dinas Pendidikan dan Kebudayaan Provinsi Riau. (2015). Validasi data SLB, SMPLB, SMLB Provinsi Riau. Pekanbaru: Kemendikbud

Efendi, F. \& Makhfudli. (2009). Keperawatan kesehatan komunitas. Jakarta: Salemba Medika

Effendi, I. F. (2014). Pengetahuan ibu, pola asuh makan dan pola konsumsi gluten kasein pada anak autis di jakarta dan bogor. Diperoleh dari http://repository.ipb.ac.id. 5 Juli 2017. Skripsi dipublikasikan

Ginanjar, A. S. (2008). Paduan praktis mendidik anak autis. Menjadi orang tua istimewa. Jakarta: PT Dian Rakyat

Graha, C. (2007). Panduan bagi orang tua untuk memahami perannya untuk membantu keberhasilan pendidikan anak. Jakarta: Kelompok Gramedia

Harjowinoto, S. \& Susanto, H. (2008). Muda berinvsetasi, tua menikmati, mati masuk surge. Jakarta: Gramedia

Harnilawati. (2013). Konsep dan proses keperawatan keluarga. Sulawesi Selatan: Penerbit Pustaka As Salam

Hazliansyah. (2013). 112.000 Anak Indonesia Diperkirakan Menyandang Autisme. News Republika. Diperoleh dari http://www.republika.co.id/berita/nasional/umum. 15 Februari $\underline{2017}$

Hidayat, D. R. (2009). Ilmu perilaku manusia pengantar psikologi untuk tenaga kesehatan. Jakarta: CV. Trans Info Media

Kartajaya, H. (2005). Winning the mom market in indonesia. Jakarta: Gramedia Pustaka Utama

Khairani, H. M. (2016). Psikologi umum. Yogyakarta: Aswaja Pressindo

Kurnia, N. W., Supiyati, S. \& Khairunnisa, A. (2014).. Hubungan sikap ibu terhadap motivasi dalam merawat anak dengan autisme di sekolah luar biasa $-c$ negeri pembina dan yayasan borneo autisme therapy center Banjarmasin provinsi Kalimantan Selatan tahun 2013. Jurkessia. Vol V, No $1 . \quad$ Diperoleh dari https://www.google.com/Fjournal.stikeshb.ac.id 1 April 2017

Kusumastuti, A. N. (2014). Stres ibu tunggal yang memiliki anak autis. Jurnal Psikologi Vol. 2 No. 7. Diperoleh dari https://www.google.com/.gunadarma.ac.id. 1 Juli 2017

Maizan, S. H., Karmiyati, D. \& Anwar, Z. (2014). Dukungan sosial dan stres pada ibu yang memiliki anak berkebutuhan khusus. Diperoleh dari http://mpsi.umm.ac.id/files/file/Prosiding/20Unmer-1.pdf 22 Juli 2017

Malahayati \& Hairunnisa, A. (2009). Ibu cerdas anak pintar. Depok: Rumah Ide 
Mashabi, N. A., \& Tajudin, N. R. (2009). Pengetahuan gizi ibu dan pola makan anak autis. $\begin{array}{lllllll}\text { Makara, Kesehatan } & \text { Vol } & \text { 13. } & \text { No } & \text { 2. } & \text { Diperoleh dari }\end{array}$ http://journal.ui.ac.id/index.php/health/article/. 5 Juli 2017

Milyawati, L. (2008). Dukungan keluarga, pengetahuan dan persepsi ibu serta hubungannya dengan strategi koping ibu pada anak dengan gangguan autism spectrum disorder (ASD). Diperoleh dari https://core.ac.uk/download/pdf. 23 Juli 2017. Skripsi dipubllikasikan

Muliana, Putri, Y. S. E., \& Panjaitan R. U. (2014). Pengaruh karakteristik orang tua terhadap jenis pola asuh dalam merawat anak penyandang autisme. Diperoleh dari http://lib.ui.ac.id/naskahringkas/2016-05/S57147-Muliana. 3 Juli 2017

Muhith, A. (2015). Pendidikan keperawatan jiwa. Yogyakarta: CV ANDI OFFSET

Muniroh, S. M. (2010). Dinamika resiliensi orang tua anak autis. Jurnal Penelitian Vol 7. No 2. Diperoleh dari http://download.portalgaruda.org/article. 25 Oktober 2016

Naina, V. O. (2012). Hubungan antara persepsi dukungan sosial dan penerimaan ibu yang memiliki anak autistik. Diperoleh dari http://thesis.binus.ac.id/doc/pdf. 5 Juli 2017. Skripsi dipublikasikan

Noor, M., Indriati, G., \& Elita, V. (2014). Pengalaman ibu dalam merawat anak autis usia sekolah. JOM PSIK. Vol 1. No. 2. Diperoleh dari http://download.portalgaruda.org/article. 25 Oktober 2016

Pujiastuti, U. (2014). Hubungan antara dukungan ayah, pengetahuan ibu tentang anak autis dan religius (dimensi praktik agama) dengan penerimaan ibu terhadap anak autis. Diperoleh dari http://eprints.ums.ac.id/31503/11/Naskah Publikasi.pdf. 22 Juli 2017. Skripsi dipublikasikan

Pratiwi, R. A. \& Dieny, F. F. (2014). Hubungan skor frekuensi diet bebas gluten bebas casein dengan skor perilaku autis. Journal of nutrition collage Vol 3. No 1. 5 Juli 2017. Diperoleh dari http://ejournal-s1.undip.ac.id.

Rahmawati, N. A., Machmuroch, \& Nugroho, A. A. 2013. Hubungan antara penerimaan diri dan dukungan sosial dengan stress ibu yang memiliki anak autis di SLB Autis di Surakarta. Diperoleh dari http://candrajiwa.psikologi.fk.uns.ac.id/index.php. 24 Juli 2017

Rezky, B. (2010). Be a smart parent, cara hebat mengasuh anak ala supernanny. Yogyakarta: Jogja Bangkit Publisher

Ria, R. T. T. M. (2011). Pengalaman ibu merawat anak autistik dalam memasuki usia remaja.

Diperoleh dari https://www.google.com/pdf. 5 Juli 2017. Skripsi dipublilkasikan

Saam, Z. \& Wahyuni, S. (2013). Psikologi keperawatan. Jakarta: Rajawali Pers

Sabri, L. \& Hastono, S. P. (2014). Statistik Kesehatan. Jakarta: Rajawali Pers 
Saputra, L. S. (2007). Menumbuhkan nasionalisme dan patriotism. Bandung: PT Setia Purna Inves

Sari, P. A., Jumaini., \& Hasanah, O. (n.d). Hubungan konsep diri orang tua dengan motivasi dalam merawat anak retardasi mental. Diperoleh dari http://repository.unri.ac.id. 6 Juli 2017

Sarosa, P. (2005). Kiat praktis membuka usaha. Becoming young entrepreneur. Jakarta: PT Elex Media Komputindo

Siregar, J. (2016). Alhamdulillah.. anakku autis. Yogyakarta: Diandra Kretif

Supartini, Y. (2004). Buku ajar konsep keperawatan anak. Jakarta: EGC

Surbakti. (2009). Kenalilah anak remaja anda. Jakarta: PT Elex Media Komputindo

Tim Pengembangan IImu Pendidikan. (2007). IImu dan aplikasi pendidikan. Jakarta: PT. Imperial Bakti Utama

Wijaksono, R. (2016). Studi kasus tentang pengaruh dukungan sosial dalam membangun penerimaan orang tua terhadap anaknya yang autis. E-Journal Bimbingan dan Konseling. Edisi 6 Tahun ke 5. Diperoleh dari http://journal.student.uny.ac.id 25 Oktober 2016

Wirakusuma, E. P. (2010). Sehat cara al-qur'an dan hadis. Jakarta: Mizan Publika

Wuryanano, (2007). The 21 principles to build and develop fighting spirit. Jakarta: PT Elex Media Komputindo 